\title{
Liquefaction phenomena along the paleo-Reno River caused by the May 20, 2012, Emilia (northern Italy) earthquake
}

\author{
Giorgos Papathanassiou ${ }^{1}$, Riccardo Caputo ${ }^{2,}$, Dimitra Rapti-Caputo $^{2}$ \\ ${ }^{1}$ Aristotle University of Thessaloniki, Department of Geology, Thessaloniki, Greece \\ ${ }^{2}$ Università di Ferrara, Dipartimento di Fisica e Scienze della Terra, Ferrara, Italy
}

\section{Article history}

Received July 23, 2012; accepted September 18, 2012.

Subject classification:

Seismic hazard assessment, Po Plain, Morphogenic earthquakes.

\section{Introduction}

On the May 20, 2012 (04:03:52 local time; 02:03:52 UTC), a moderate earthquake $\left(M_{L}\right.$ 5.9) [Scognamiglio et al. 2012, this volume] with a focal mechanism showing E-W-trending, S-dipping, reverse-faulting occurred in the eastern sector of the alluvial plain of the Po River, close to the border between the Regions of Emilia-Romagna and Lombardia (northern Italy). The tectonic structure is completely blind, but it was well known from a dense grid of seismic profiles for hydrocarbon explorations [e.g., Pieri and Groppi 1981, Toscani et al. 2009]. The earthquake triggered extensive liquefaction-induced ground effects at the surface, and caused severe structural damage to nonreinforced masonry and precast industrial buildings within the broader epicentral area. The hypocenter was at $44.89^{\circ} \mathrm{N}, 11.23^{\circ} \mathrm{E}$, at a depth of $6.3 \mathrm{~km}$ [Scognamiglio et al. 2012], while the maximum acceleration was recorded in Mirandola, with peak ground acceleration $310 \mathrm{~cm} / \mathrm{s}^{2}$ and $264 \mathrm{~cm} / \mathrm{s}^{2}$ along the vertical and horizontal components, respectively [Bozzoni et al. 2012, this volume].

In this report, we focus on a zone including the Sant'Agostino, San Carlo and Mirabello villages (west Ferrara Province), which were built along an abandoned reach of the Reno River and where liquefaction phenomena were particularly diffuse, with very intense local effects (Figure 1). The map in Figure 1 is based on original data collected in the days following the mainshock (and before the event of May 29, 2012) and locally integrated with data published by ISPRA [2012]. Similar maps have also been presented by other geological teams [e.g., Decanini et al. 2012, EMERGEO Working Group 2012], including of the western sector of the epicentral area and the manifestations that occurred during the second major earthquake. However, for the aims of this report that focuses on the Sant'Agostino, San Carlo and Mirabello case study, they will be not discussed.

Based on stratigraphic reconstructions from boreholes and penetrometric tests, and on new direct measurements within numerous water wells, a preliminary conceptual hydrogeological model for the first ca. $30 \mathrm{~m}$ is also proposed for the investigated area. This hydrogeological model provides essential information for the liquefaction susceptibility discussed in this report. Grain-size analyses of ejected material collected a few days after the event in several locations were also carried out, and are here discussed in relation to the classical susceptibility criteria proposed by Tsuchida [1971]. In addition, a preliminary evaluation of the macroseismic intensity is performed based on the Environmental Seismic Intensity (ESI) scale [Michetti et al. 2007].

\section{Earthquake-induced ground effects}

A few hours after the event, a post-earthquake field survey was organized to report the coseismic effects and to compile a map of their spatial distribution (Figure 1). As this survey began a few hours after the mainshock, this provided the opportunity to observe, measure, photographically record, and map the sites where the sandy material was ejected, before the residents and local authorities started removing the liquefied sandy materials from the courtyards and roads.

During this post-event investigation, more than 150 locations were surveyed, with the focus on a zone $8 \mathrm{~km}$ long and $0.5 \mathrm{~km}$ wide, with the parameters that characterize the surface liquefaction manifestations were measured and recorded carefully. In particular, the length and width of vent fractures, and the diameter of the sand craters were measured, and samples were collected from ejected materials at representative sites. The length of the liquefaction-induced surface ruptures varied, as expected, from a few centimetres to more than $10 \mathrm{~m}$, and locally they were reported as up to $50 \mathrm{~m}$ [Lai et al. 2012]. The width variation of the cracks ranged from a few centimetres to $30 \mathrm{~cm}$. The ejection of sandy material occurred through conduits and fractures in farmed fields, although the most spectacular effects affected pavements and large-diameter water wells within the urban- 


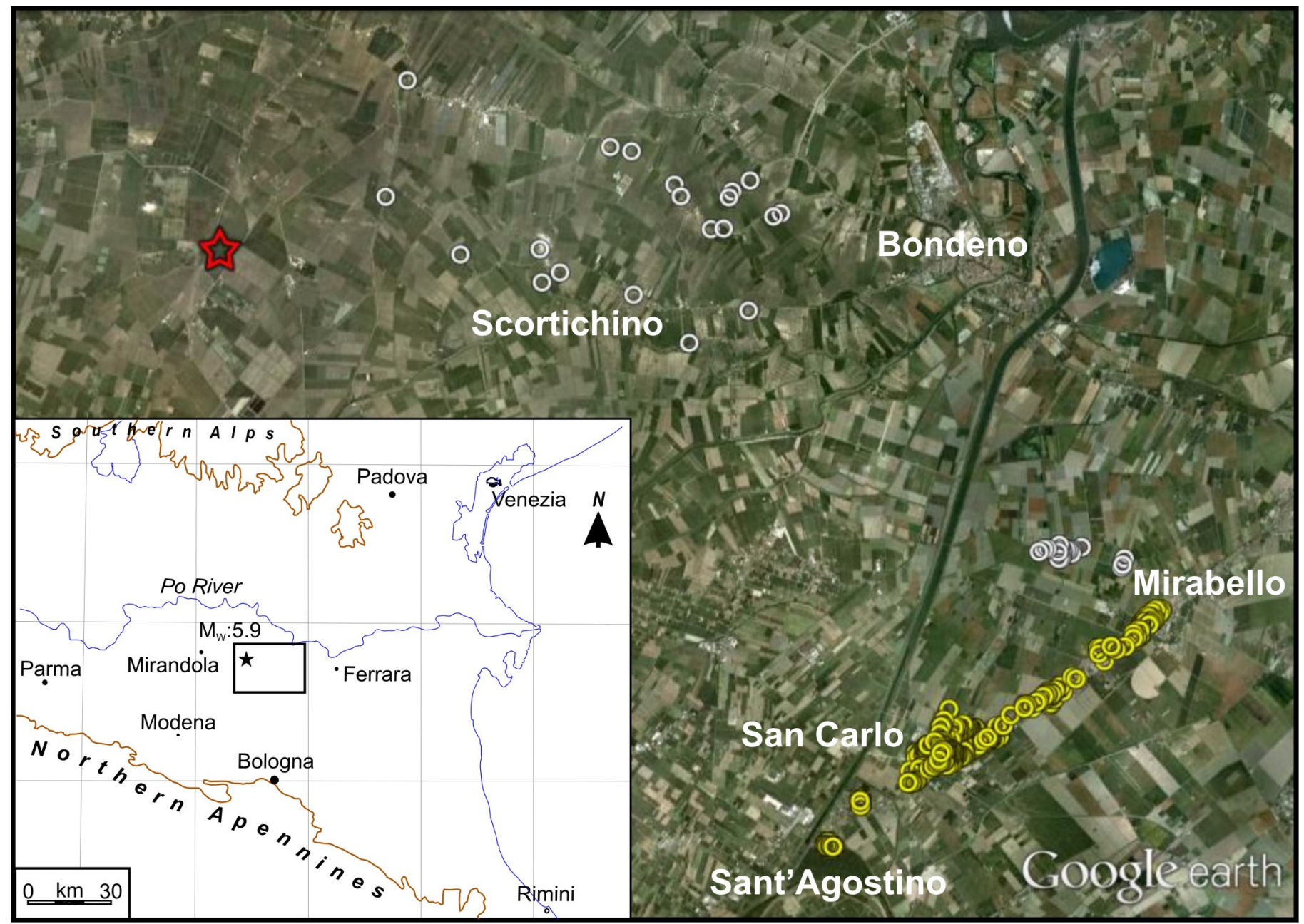

Figure 1. Map of the spatial distribution of the liquefaction-induced surface evidence within the west Ferrara Province from original data (yellow circles) and from the ISPRA [2012] report (white circles). Red star, May 20, 2012, earthquake epicenter. Base map from Google Inc. (2012).

ized areas (Figure 2). As a consequence, the number of sand craters and volcanoes were significantly lower than the vent fractures, but above all, their location and geometry was strongly controlled by the artificial discontinuities within the paving and other infrastructures. The diameter in these cases ranged from $4 \mathrm{~cm}$ up to $40 \mathrm{~cm}$.

Lateral spreading due to liquefaction and the consequent upward injection of sandy material is also well documented by electrical resistivity tomographies [Abu-Zeid et al. 2012, this volume], and this phenomenon induced structural damage within the urbanized areas, including broken pipelines and differential settling, causing minor damage to buildings locally.

In addition, short interviews with the villagers were carried out relating to the ejection of fluids and sandy material. The questions posed focused on the timing of the ejection phenomena, relative to the occurrence of the mainshock, the duration of the outflow, and the height of the ejection with respect to the ground surface. Important outcomes of these interviews were: (i) most of the sandy material within the three urban areas that was focused on (Mirabello, San Carlo, Sant'Agostino) was ejected through large diameter water wells; (ii) the ejection of sandy material started almost at the same time as the mainshock; and (iii) in the first seconds/ minutes of the ejection process, clear water came to the surface first, only later mixed with sand. The duration of the phenomenon commonly lasted up to a few minutes, although at one site ( $\left.44^{\circ} 48^{\prime} 03^{\prime \prime} \mathrm{N}, 11^{\circ} 24^{\prime} 34^{\prime \prime} \mathrm{E}\right)$ an eyewitness stated that the outpouring of water after the major sand ejection phenomenon lasted for several hours. Differences in the amounts of material and timing are likely to be due to local geological, hydrogeological and anthropogenic conditions.

For the height of the ejection, the most characteristic report is that from a well at the center of San Carlo $\left(44^{\circ} 48^{\prime} 15.39^{\prime \prime} \mathrm{N}\right.$, $\left.11^{\circ} 24^{\prime} 35.14^{\prime \prime} \mathrm{E}\right)$, where the liquefied material was ejected up to $2 \mathrm{~m}$ above the ground surface, and with such intensity as to damage the well. Taking into account that the depth to the water at the site was ca. $5 \mathrm{~m}$ (see next section), it can be assumed that the total height of the ascent was more than $7 \mathrm{~m}$. Considering the average density of the outflowing material (a mixture of water and sand), this implies a fluid pressure of probably more than one bar $(0.1 \mathrm{MPa})$. Similar ascent and ejection of sand through wells was triggered by the Friuli 1976, northeastern Italy, earthquake [Sirovich 1996].

To assess the macroseismic intensity in the area studied, we applied the ESI scale [Michetti et al. 2007], as the gener- 
ated geological effects were widespread and extensive. Thus, taking into account the length and width of the surface ruptures, and the dimensions of vent fractures and sand boils of liquefaction phenomena, we conclude that the macroseismic intensity should be evaluated as VIII in the area of San Carlo. In particular, according to the ESI definition of intensity degrees [Michetti et al. 2007], a value of VII-VIII is appropriate in areas where fractures up to $50 \mathrm{~cm}$ wide and up to hundreds of meters long are commonly observed in loose alluvial deposits. Decametric cracks are common in paved roads, and liquefaction can be frequent in the epicentral area. Localized lateral spreading and settling (up to ca. $30 \mathrm{~cm}$ ) can result in the most typical effects of sand boiling up to ca. $1 \mathrm{~m}$ in diameter.

\section{Hydrogeological model}

The conceptual shallow of the hydrogeological model of the broader Ferrara Province is characterized by the presence of two aquifer systems. The first is superficial and semiconfined or locally unconfined (A0 according to Molinari et al. [2007]), and the second is deeper and always confined (A1; Regione Emilia-Romagna and ENI-AGIP [1998]).

Within the investigated area, and based on published [Emilia-Romagna Region Open file] and unpublished stratigraphic data, the A0 aquifer system consists of silty-sandy and locally peat and sandy lenses, with variable grain-sized distributions containing a semi-confined and locally unconfined aquifer. According to interviews with the villagers, the piezometric level in many wells showed limited variations even after a long exploitation period, thus indicating that the aquifer bodies belonging to $\mathrm{A} 0$ are commonly hydraulically inter-connected. Only minor lenses were probably isolated, as suggested by their complete draining and a longer recharge time following a few hours of pumping.

The exploitation of this aquifer system is performed using boreholes of about $1 \mathrm{~m}$ in diameter, which were often

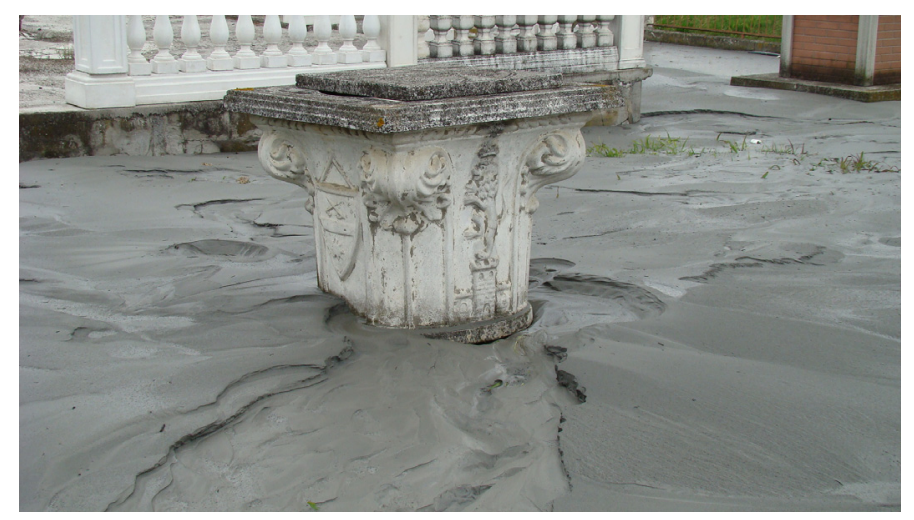

Figure 2. Example of sand ejection from a large-diameter water well at the base of the levee associated with an abandoned reach of the Reno River (San Carlo-Sant'Agostino road).

excavated many years ago, commonly to a depth of $7 \mathrm{~m}$ to 13 $\mathrm{m}$. This traditional water-well excavation and their architecture was maintained by local people up to the last decades. Before the aqueduct network reached these areas, these large diameter wells were the only means to provide the water for every domestic use.

The spatial distribution and the geometric characteristics of these highly heterogeneous aquifer units were largely influenced by the latest Quaternary geomorphological and sedimentary evolution of the territory, and especially by the presence and path of active and abandoned channels and outflow cones [e.g. Rapti-Caputo 2000]. Within the investigated area, the thickness of the aquifer varies from between a few meters to $6 \mathrm{~m}$ to $8 \mathrm{~m}$, in agreement with the paleo-reach of the Reno River (Figure 3).

The hydraulic conductivity of the A0 aquifer system was preliminarily estimated based on the available stratigraphic data and the grain-size analyses we performed from collected samples of ejected material (see next section). According to Hazen [1911], this parameter varies from between $10^{-5}$ and $10^{-4} \mathrm{~m} / \mathrm{s}$, thus indicating highly permeable layers. The prin-

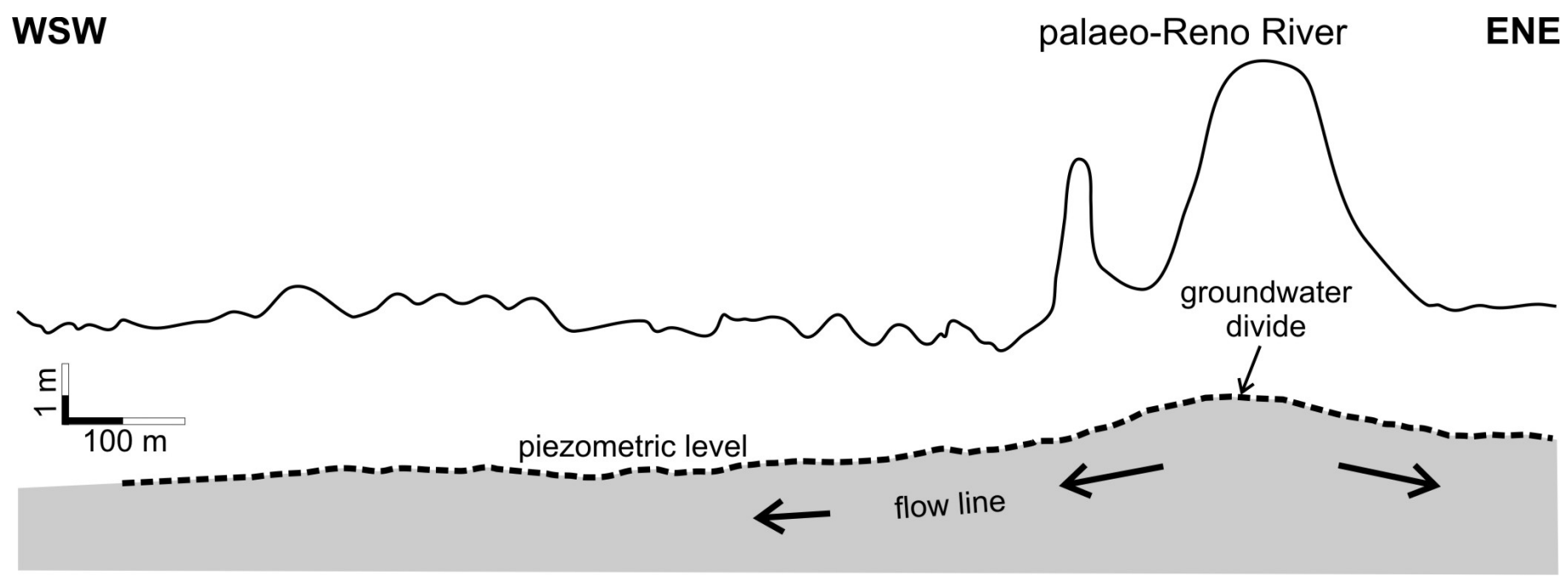

Figure 3. Topographic profile (black line) drawn from a lidar-based DEM, and piezometric level of the unconfined aquifer system (A0), as reconstructed from water-well measurements a few weeks after the seismic event. 


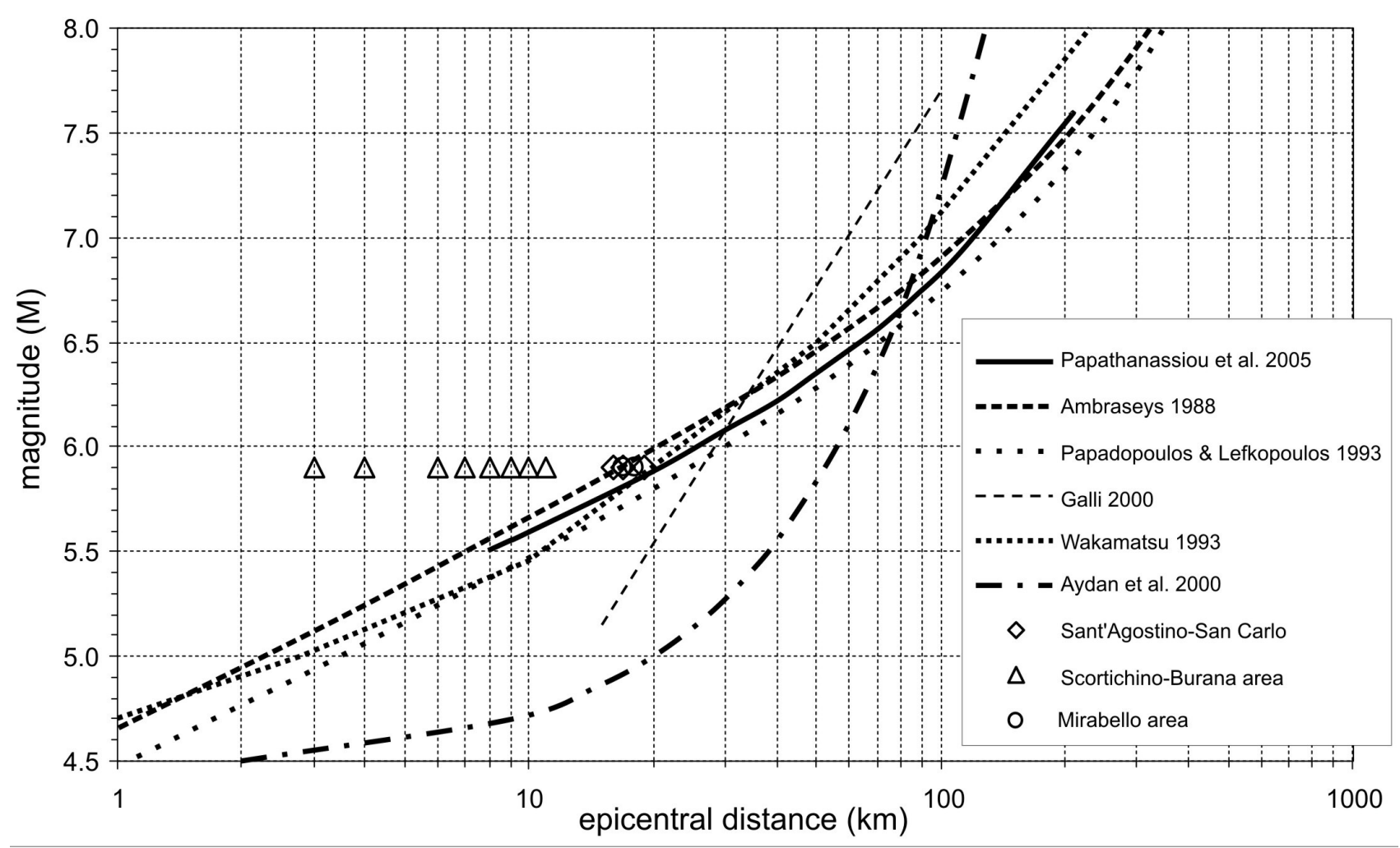

Figure 4. Distribution of the liquefied sites based on their epicentral distances and comparison with the triggering curves proposed by several studies for the assessment of liquefaction susceptibility.

cipal recharge of the aquifer was primarily due to vertical infiltration from the precipitation, and secondarily to recharges via lateral infiltration from the active hydrographic network, as documented in nearby areas with a comparable hydrogeological-geomorphological setting [e.g. Rapti-Caputo 2000]. Indeed, the local alimentation is shown by high values of tritium (3-6 TU) that show that the mean residence time of the water in the underground reservoir is only 2 years to 5 years [Rapti-Caputo 2008, Rapti-Caputo and Martinelli 2009]. The piezometric level varies by about $1.5 \mathrm{~m}$ to $2.5 \mathrm{~m}$ during the hydrological year, due to the variability of both the seasonal precipitation and the hydrometric level within the hydrographic network [Rapti-Caputo 2008, ARPA GdL 2010].

Based on a campaign of measurements specifically carried out for 45 wells during the weeks following the earthquake, the water depths were about $1.4 \mathrm{~m}$ to $3.0 \mathrm{~m}$ in the interfluvial plain, showing deeper values ( $4 \mathrm{~m}$ to $5 \mathrm{~m}$ from the surface) in the boreholes located along the levees of the paleo-Reno River. This hydrogeological setting is shown in Figure 3, where the influence of the paleo-channel on the direction of the groundwater flow is evident for generating a marked groundwater divide.

A low permeability layer that consists prevalently of clay and silt locally alternating with peat lenses separates the unconfined (A0) from the underlying confined aquifer (A1) located about $16 \mathrm{~m}$ to $18 \mathrm{~m}$ below the surface [Rapti-Caputo 2008, Regione Emilia-Romagna GdL-liquefazione 2012]. The latter aquifer body consists of high permeability sediments (mainly sand), and has a thickness of between $4 \mathrm{~m}$ and $9 \mathrm{~m}$.

\section{Liquefaction-related effects}

To evaluate the susceptibility to liquefaction of the soil deposits within the investigated area, we followed the procedure recommended by the Manual for Zonation on Seismic Geotechnical Hazards, prepared by The Technical Committee for Earthquake Geotechnical Engineering, TC4, of the International Society for Soil Mechanics and Geotechnical Engineering, and published by The Japanese Geotechnical Society [TC4, 1999]. Initially, the relationship between the epicentral distance of liquefied sites and earthquake magnitude was examined. The epicentral distances of the villages of Sant'Agostino, San Carlo and Mirabello are 16 $\mathrm{km}, 17 \mathrm{~km}$ and $19 \mathrm{~km}$, respectively (Figure 4). In addition, the epicentral distances of the liquefied area of ScortichinoBurana, documented by ISPRA [2012], varied from $3 \mathrm{~km}$ to $11 \mathrm{~km}$, while the zone situated to the north of Mirabello is about $17 \mathrm{~km}$ from the epicenter. According to several empirical relationships between magnitude and epicentral distance (Figure 4), these areas should be clearly considered as susceptible to liquefaction for an earthquake of $\mathrm{M}_{\mathrm{L}} 5.9$, as they lie above most of the proposed curves, with the only possible exceptions of some sites in the Mirabello area.

Differences between the proposed empirical relationships (and hence the curves represented in Figure 4) are due to the different datasets used in these studies. For example, Ambraseys [1988] used a worldwide set of liquefaction data, while Papadopoulos and Lefkopoulos [1993] updated the dataset collected by Ambraseys with 30 new cases from Greek earthquakes and with three other ones. Wakamatsu 


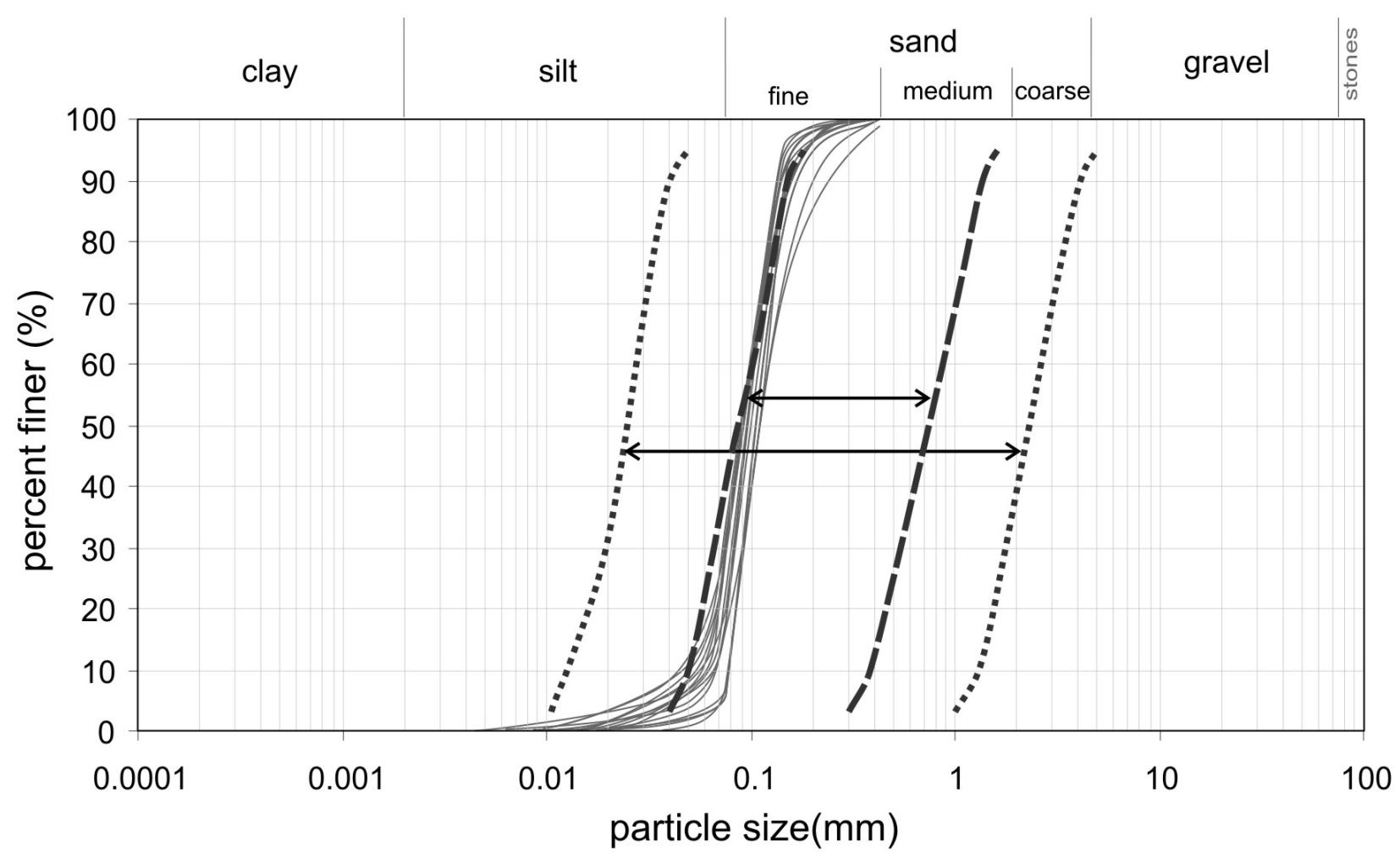

Figure 5. Comparison between the grain-size distribution curves of the collected samples and the boundary curves for liquefiable (dashed lines) and probable liquefiable (dotted lines) soils, as suggested by Tsuchida [1971]. Similar critical curves were proposed by EN 1998-1 [2004] and NTC [2008].

[1993] extended the work of Kuribayashi and Tatsuoka [1975] by adding 46 new data points from Japanese earthquakes, while Galli [2000] and Aydan et al. [2000] re-evaluated the seismic parameters of Italian and Turkish earthquakes, respectively, using data from after 1900 . The curve suggested by Papathanassiou et al. [2005] was constructed based on liquefaction phenomena that were reported after 1900 in Greece.

The sites where liquefaction-induced ground effects are documented generally consist of Holocene fluvial sediments and locally man-made deposits. The villages of Sant'Agostino, San Carlo and Mirabello were founded upon the levees of a former reach of the Reno River [Graziani et al. 1992, Castiglioni et al. 1999, Caputo et al. 2012 (this volume)]. This was for the obvious reason that this site was (and still is) $3 \mathrm{~m}$ to $5 \mathrm{~m}$ higher with respect to the surrounding alluvial plain, which at that time (XV-XVIII century) was repeatedly flooded. Moreover, the presence of a locally sandy substratum associated with the crevasse deposits ascertained better stability for house foundations, in contrast to other sectors of the plain where the muddy material was not suitable for construction. Notwithstanding these historical and social reasons, these morphological, stratigraphic and hydrogeological conditions were characterized by: (i) topographic gradients; (ii) the presence of cohesionless deposits; and (iii) a depth of the water table of less than $1 \mathrm{~m}$ locally. This represented the perfect preparatory factors for liquefaction, just waiting for sufficient shaking to trigger the physical process. Eventually, on May 20, 2012, sufficient shaking occurred, and this caused locally important and widespread liquefaction phenomena.
At the surface, this produced small-scale structural damage, mainly due to lateral spreading ( $44^{\circ} 48^{\prime} 22^{\prime \prime} \mathrm{N}, 11^{\circ} 24^{\prime} 46^{\prime \prime} \mathrm{E}$ ) and differential settling (44 $\left.49^{\prime} 29^{\prime \prime} \mathrm{N}-11^{\circ} 27^{\prime} 26^{\prime \prime} \mathrm{E}\right)$.

Similar coseismic effects within old and/or former river channel zones are well documented for at least three recent earthquakes: Luzon Philippines in 1990, Niigaten Chuetsuoki, Japan, in 2007 and Darfield, New Zealand, in 2010 [Wotherspoon et al. 2012]. This confirms that this type of morphological setting is favorable for earthquake-induced surface ruptures and liquefaction phenomena. The above conclusion is in agreement with the characterization of this type of deposit as highly susceptible to liquefaction during strong seismic shaking, based on the geological criteria that were suggested by Youd and Perkins [1978].

The samples collected during the field survey were analyzed in the Laboratory of Engineering Geology and Hydrogeology of the Department of Geology at the Aristotle University of Thessaloniki (Greece), to obtain the grain-size distribution, the liquid limit, and the plasticity index [e.g., Kramer 1996] (Figure 5). Based on the Unified Soil Classification System (USCS), samples are classified (see Table 1) as silty sand (SM) with non-plastic fine particles, and fine sand (SP-SM). The fines content of the samples analyzed varied from $6 \%$ to $12 \%$ for the SP-SM, and from $20 \%$ to $34 \%$ for the $\mathrm{SM}$. The results suggest that the majority of the ejected samples had probably come from a unique sedimentary layer. The probable source level was identified using cone penetration tests and cores, which was carried out within the investigated area in a similar morphological, hydrogeological 


\begin{tabular}{|c|c|c|c|c|}
\hline$a / a$ & Longitude & Latitude & $\begin{array}{c}\text { USCS } \\
\text { classification }\end{array}$ & $\begin{array}{c}\text { Fines content } \\
(\%)\end{array}$ \\
\hline S1 & $44^{\circ} 48^{\prime} 16.85^{\prime \prime}$ & $11^{\circ} 25^{\prime} 08.30^{\prime \prime}$ & SM & 31 \\
\hline S2 & $44^{\circ} 48^{\prime} 17.19^{\prime \prime}$ & $11^{\circ} 25^{\prime} 07.42^{\prime \prime}$ & SM & 29 \\
\hline S3 & $44^{\circ} 48^{\prime} 17.73^{\prime \prime}$ & $11^{\circ} 24^{\prime} 37.49^{\prime \prime}$ & SP-SM & 7 \\
\hline S4 & $44^{\circ} 48^{\prime} 12.68^{\prime \prime}$ & $11^{\circ} 24^{\prime} 25.74^{\prime \prime}$ & SP-SM & 6 \\
\hline S5 & $44^{\circ} 48^{\prime} 10.61^{\prime \prime}$ & $11^{\circ} 24^{\prime} 30.99^{\prime \prime}$ & SM & 18 \\
\hline S6 & $44^{\circ} 48^{\prime} 08.99^{\prime \prime}$ & $11^{\circ} 24^{\prime} 33.14^{\prime \prime}$ & SM & 17 \\
\hline S7 & $44^{\circ} 48^{\prime} 25.16^{\prime \prime}$ & $11^{\circ} 24^{\prime} 45.67^{\prime \prime}$ & SM & 32 \\
\hline S8 & $44^{\circ} 48^{\prime} 20.28^{\prime \prime}$ & $11^{\circ} 24^{\prime} 57.20^{\prime \prime}$ & SM & 34 \\
\hline S9 & $44^{\circ} 47^{\prime} 58.54^{\prime \prime}$ & $11^{\circ} 24^{\prime} 09.06^{\prime \prime}$ & SM & 23 \\
\hline S10 & $44^{\circ} 47^{\prime} 55.64^{\prime \prime}$ & $11^{\circ} 24^{\prime} 04.41^{\prime \prime}$ & SP-SM & 8 \\
\hline S11 & $44^{\circ} 47^{\prime} 50.16^{\prime \prime}$ & $11^{\circ} 24^{\prime} 03.68^{\prime \prime}$ & SM & 18 \\
\hline S12 & $44^{\circ} 48^{\prime} 35.81^{\prime \prime}$ & $11^{\circ} 25^{\prime} 47.42^{\prime \prime}$ & SM & 30 \\
\hline $\mathrm{S} 13$ & $44^{\circ} 49^{\prime} 37.12^{\prime \prime}$ & $11^{\circ} 27^{\prime} 41.68^{\prime \prime}$ & SM & 20 \\
\hline S14 & $44^{\circ} 49^{\prime} 29.57^{\prime \prime}$ & $11^{\circ} 27^{\prime} 27.13^{\prime \prime}$ & SM & 30 \\
\hline
\end{tabular}

Table 1. Grain size characteristics of the collected material.

and stratigraphic setting [Regione Emilia-Romagna GdL-liquefazione 2012]. This source unit consists of a medium-tocoarse sand layer at a depth of $7 \mathrm{~m}$ to $8 \mathrm{~m}$ from the surface, which varies in thickness between $1.5 \mathrm{~m}$ and $4 \mathrm{~m}$, and which probably recorded large crevasse splays and overbank flood episodes. Due to the stratigraphic setting and the hydrogeological framework, this layer represents a semi-confined aquifer that is characterized by a high degree of liquefaction susceptibility. The presence of a non-liquefied silty-clayey cap layer and the occurrence of some erosion during the upward flow along the dikes and conduits might have caused an overestimation of the fines content of the ejected material. Table 1 lists the results of the collected samples that were provided by the laboratory testing, including the fines content (\%), the classification (USCS), and their geographic location.

The results of the grain-size analyses of the samples are also compared with the curves proposed by Tsuchida [1971] for soils at uniform grading, as shown in Figure 5. The grain-size distribution curves obtained fall within the suggested range for liquefaction conditions, therefore characterizing these deposits as susceptible to liquefaction in terms of their grain size.

\section{Concluding remarks}

The May 20, 2012, Emilia earthquake triggered extensive liquefaction-induced ground effects at the surface and caused structural damage to unreinforced masonry and precast industrial buildings within the broader epicentral area. The post-earthquake field survey organized a few hours after the event focused on a zone $8 \mathrm{~km}$ long and $0.5 \mathrm{~km}$ wide, and it was devoted to the reporting of the co-seismic effects and to compile a map of their spatial distribution. The lengths of the liquefaction-induced surface ruptures varied from a few centimeters to more than $10 \mathrm{~m}$, while the width variation of the cracks was not so great, ranging from a few centimeters to $30 \mathrm{~cm}$. The ejection of sandy material occurred through conduits and fractures in farmed fields, although the most spectacular effects affected roads, pavements and water wells within the urbanized areas.

In addition, short interviews with the villagers were carried out concerning the ejection of fluids and sandy material. The outcomes of these interviews are that most of the sandy material within the urban areas of Mirabello, San Carlo and Sant'Agostino was ejected through water wells of large diameter, which are typical of the region, and exploited the first unconfined aquifer. The phenomenon started almost at the same time as the mainshock, and in the first seconds/minutes of the ejection process clear water came to the surface first, only afterwards mixed with sand.

Furthermore, samples of the ejected material were collected, to obtain grain-size distribution, liquid limits and plasticity indices. Based on the USCS, the materials were classified as SM with non-plastic fine particles, and SP-SM. The fines content of these deposits varied from $6 \%$ to $12 \%$ for the SP-SM and from $20 \%$ to $34 \%$ for the SM. The results suggest that the majority of the ejected samples had probably come from the same sedimentary layer.

A preliminary outcome of these field surveys is that the studied area has suffered large-scale liquefaction-induced manifestations that should be considered as secondary coseismic effects (i.e., not directly associated with the upwards propagation of the fault rupture). Although liquefaction phe- 
nomena were diffuse in the epicentral area and in general the liquefaction potential might be characterized as 'high' for recent alluvial plains, only small-scale liquefaction-induced structural damage was documented [Galli et al. 2012, Tertulliani et al. 2012, this volume].

Taking into account that the geological (stratigraphic, morphological, hydrogeological seismotectonic) setting of the investigated area is comparable with those of many other sectors of the broader Po Plain, as well as worldwide, and due to the abundance of liquefaction-related features produced here, the investigated case study represents a valuable example for future investigations devoted to better evaluation of liquefaction hazard.

Acknowledgements. The authors thank the Servizio Geologico, Sismico e dei Suoli, Regione Emilia-Romagna for providing the lidar-based DEMs and preliminary access to the sedimentary cores drilled in the investigated area.

\section{References}

Abu Zeid, N., S. Bignardi, R. Caputo, G. Santarato and M. Stefani (2012). Electrical resistivity tomography investigation of coseismic liquefaction and fracturing at San Carlo, Ferrara Province, Italy, Annals of Geophysics, 55 (4); doi:10.4401/ag-6149.

Ambraseys, N. (1988). Engineering seismology, J. Earthq. Eng. Struct. Dyn., 17, 1-105.

ARPA GdL (2010). Supporto tecnico alla Regione EmiliaRomagna per la ricostruzione del quadro conoscitivo relativo ai principali acquiferi freatici di pianura; http:/ / www.arpa.emr.it/cms3/documenti/_cerca_doc/acqua/ piacenza/sotterranee/freatico_pc2010_allegati.pdf

Aydan, O., R. Ulusay, H. Kumsar and E. Tuncay (2000). Site investigation and engineering evaluation of the DuzceBolu earthquake of November 12, 1999, Turkish Earthquake Foundation, Instanbul, Report No. TDV/DR 09-51, $307 \mathrm{pp}$.

Bozzoni, F., C.G. Lai and L. Scandella (2012): Preliminary results of ground-motion characteristics, Annals of Geophysics, 55 (4); doi:10.4401/ag-6121.

Caputo, R., K. Iordanidou, L. Minarelli, G. Papathanassiou, M.E. Poli, D. Rapti-Caputo, S. Sboras, M. Stefani and A. Zanferrari (2012). Geological evidence of pre-2012 seismic events, Emilia-Romagna, Italy, Annals of Geophysics, 55 (4); doi:10.4401/ag-6148.

Castiglioni, G., A. Biancotti, M. Bondesan, G.C. Cortemiglia, C. Elmi, V. Favero, G. Gasperi, G. Marchetti, G. Orombelli, G.B. Pellegrini and C. Tellini (1999). Geomorphological map of the Po Plain, Italy, at a scale of 1:250.000, Earth Surf. Proc. Land., 24, 1115-1120.

Decanini, L.D., D. Liberatore, L. Liberatore and L. Sorrentino (2012). Preliminary Report on the 2012, May 20, Emilia Earthquake, vers. 1, http://www.eqclearinghouse.org/2012-05-20-italy-it/
EMERGEO working group (2012). Rilievi geologici di terreno effettuati nell'area epicentrale della sequenza sismica della Pianura Padana Emiliana del maggio-giugno 2012, Rapporto 04.06.2012; http:/ / emergeo.ingv.it/images/ emergeo/Emergeo04062012.pdf

EN 1998-1 (2004). Eurocode 8 - Design of Structures for earthquake resistance - Part 1: General rules, seismic actions and rules for buildings, EN 1998-1, CEN, Brussels.

Galli, P. (2000). New empirical relationships between magnitude and distance for liquefaction, Tectonophysics, 324, 169-187.

Galli, P., S. Castenetto and E. Peronace (2012). The MCS macroseismic survey of the Emilia 2012 earthquakes, Annals of Geophysics, 55 (4); doi:10.4401/ag-6163.

Graziani, S., R. Ferri and M. Bondesan (1992). Aspetti geomorfologici e problemi paleogeografici della zona fra Bondeno, Finale Emilia e Mirabello nel quadro degli antichi domini idrografici del Secchia, del Panaro e del Reno, In: S. Gelichi (ed.), Un mito e un territorio: Ansalaregina e l'Alto Ferrarese nel Medioevo, All'Insegna del Giglio, Firenze, 13-44.

Hazen, A. (1911). Discussion: dams on sand foundations, T. Am. Soc. Civ. Eng., 73, 199 pp.

ISPRA (2012). Geological effects induced by the seismic sequence started on May 20, 2012, in Emilia (Mw=5.9)Preliminary report, http:/ / www.isprambiente.gov.it/files/ progetti/inqua/inqua-primo-rapporto-emilia-2012.pdf

Kramer, S.L. (1996). Geotechnical Earthquake Engineering, Prentice Hall, New Jersey, 348-355.

Kuribayashi, E., and F. Tatsuoka (1975). Brief review of liquefaction during earthquakes in Japan, Soils Found., 15, 81-92.

Lai, C.G., F. Bozzoni, M.-D. Mangriotis, M. Martinelli, L. Scandella and F. Dacarro (2012). Geotechnical aspects of the May 20, 2012 M5.9 Emilia earthquake, Italy, version 1, July 13, 2012; http: / /www.eqclearinghouse.org/2012-0520-italy/files/2012/07/Report_GEO_Emilia_FINAL.pdf

Michetti, A.M., E. Esposito, L. Guerrieri, S. Porfido, L. Serva, R. Tatevossian, E. Vittori, F. Audemard, T. Azuma, J. Clague, V. Comerci, A. Gurpinar, J. McCalpin, B. Mohammadioun, N.A. Mörner, Y. Ota and E. Roghozin (2007). Intensity Scale ESI 2007, In: L. Guerrieri and E. Vittori (eds.), Memorie Descrittive della Carta Geologica d'Italia, Roma, 74, 53 pp.

Molinari, F.C, G. Boldrini, P. Severi, G. Duroni, D. Rapti-Caputo and G. Martinelli (2007). Risorse idriche sotterranee della Provincia di Ferrara. Regione Emilia Romagna, DB MAP Ed., Firenze, 61 pp.

NTC (2008). Norme tecniche per le Costruzioni, D.M. 14.1.2008 (Italian Building Code, in Italian).

Papadopoulos, G.A., and G. Lefkopoulos (1993). Magnitudedistance relations for liquefactionin soil from earthquakes, B. Seismol. Soc. Am., 83 (3), 925-938. 
Papathanassiou, G., S. Pavlides, B. Christaras and K. Pitilakis (2005). Liquefaction case histories and empirical relations of earthquake magnitude versus distance from the broader Aegean Region, J Geodyn., 40, 257-278.

Pieri, M., and G. Groppi (1981). Subsurface geological structure of the Po Plain, Italy, Consiglio Nazionale delle Ricerche, Progetto Finalizzato Geodinamica, Sottoprogetto Modello Strutturale, 414, Roma, 13 pp.

Rapti-Caputo, D. (2000). Risorse idriche sotterranee a est di Ferrara: indagini sul comportamento idrogeologico e idrochimico. Proposte per una gestione ottimale, Ph.D. thesis, University of Ferrara, 215 pp.

Rapti-Caputo, D. (2008). Hydrodynamic and hydrochemical monitoring of the Sant'Agostino landfill, University of Ferrara, Internal report, 180 pp. (unpublished).

Rapti-Caputo, D., and G. Martinelli (2009). Geochemical and isotopic composition of the groundwater resources of the Po River delta (Northern Italy): implications for the environmental impact, J. Hydrogeology, 17, 467-480.

Regione Emilia-Romagna (Open file). La banca dati geognostica; http: / / ambiente.regione.emilia-romagna.it/ geologia/ cartografia/webgis-banchedati/banca-datigeognostica

Regione Emilia-Romagna and ENI-AGIP (1998). Riserve idriche sotterranee della Regione Emilia-Romagna, G. Di Dio (ed.), S.EL.CA., Firenze, 120 pp.

Regione Emilia-Romagna GdL-liquefazione (2012). Primo rapporto sugli effetti della liquefazione osservati a $S$. Carlo, frazione di S. Agostino (Provincia di Ferrara); http:/ / ambiente.regione.emilia-romagna.it/geologia/ temi/sismica/liquefazione-gruppo-di-lavoro/rapporto_ sancarlo.pdf

Scognamiglio, L., L. Margheriti, F.M. Mele, E. Tinti, A. Bono, P. De Gori, V. Lauciani, F.P. Lucente, A.G. Mandiello, C. Marcocci, S. Mazza, S. Pintore and M. Quintiliani (2012). The 2012 Pianura Padana Emiliana seimic sequence: locations, moment tensors and magnitudes, Annals of Geophysics, 55 (4); doi:10.4401/ag-6159.

Sirovich, L. (1996). Repetitive liquefaction at a gravelly site and liquefaction in verconsolidated sands, Soils Found., 36 (4), 23-34.

TC4 (1999). Manual for Zonation on Seismic Geotechnical Hazards (Revised Version), The Japanese Geotechnical Society.

Tertulliani, A., L. Arcoraci, M. Berardi, F. Bernardini, B. Brizuela, C. Castellano, S. Del Mese, E. Ercolani, L. Graziani, A. Maramai, A. Rossi, M. Sbarra and M. Vecchi (2012). The Emilia 2012 sequence: a macroseismic survey, Annals of Geophysics, 55 (4); doi:10.4401/ag-6140.

Toscani, G., P. Burrato, D. Di Bucci, S. Seno and G. Valensise (2009). Plio-Quaternary tectonic evolution of the Northern Apennines thrust fronts (Bologna-Ferrara section, Italy): seismotectonic implications, B. Soc. Geol. Ital., 128
(2), 1-10.

Tsuchida, H. (1971). Estimation of liquefaction potential of sandy soils, In: Proc. 3rd Joint Meeting, US-Japan, UNJR.

Youd, T.L., and D.M. Perkins (1978). Mapping of Liquefaction induced Ground Failure Potential, J. Geotech. Eng. Div., 104, 433-446.

Wakamatsu, K. (1993). History of Soil liquefaction in Japan and Assessment of Liquefaction Potential based on Geomorphology, Ph.D. thesis, Waseda University, Tokyo, Japan, 245 pp.

Wotherspoon, L., M. Pender and R. Orense (2012). Relationship between observed liquefaction at Kaiapoi following the 2010 Darfield earthquake and former channels of the Waimakariri River, Eng. Geol., 125, 45-55.

\footnotetext{
${ }^{\star}$ Corresponding author: Riccardo Caputo, Università di Ferrara, Dipartimento di Fisica e Scienze della Terra, Ferrara, Italy; email: rcaputo@unife.it.

(C) 2012 by the Istituto Nazionale di Geofisica e Vulcanologia. All rights reserved.
} 